\title{
Research on the Impact of Social Responsibility of Tourism Listed Companies on Their Business Performance
}

\author{
Xiaolin Li \\ Xi'an University of science and technology, Xi'an, Shaanxi, China
}

\begin{abstract}
In the process of tourism development, there are some problems that can not be ignored, such as the destruction of natural environment by scenic spot development, unfair competition in the industry, and infringement of employees' rights and interests by enterprises, which directly restrict the development of tourism industry. The issue of tourism corporate social responsibility has been in the sight of global scholars and practitioners. First of all, this paper will study and analyze the relevant theories made so far by scholars and practitioners at home and abroad, to understand the research status of social responsibility of tourism listed companies at home and abroad, as well as the status quo of corporate social responsibility. Secondly, this paper selects 23 domestic tourism listed companies to collect the panel data of their social responsibility reports from 2014 to 2018, and makes an empirical analysis on the sorted panel data through the statistical software Eviews, so as to explore the impact of social responsibility of tourism listed companies on their business performance, And draw the conclusion that tourism listed companies' business responsibility has a positive impact on their business performance, but there is a certain lag in this impact. Based on the research, this paper puts forward some feasible suggestions for tourism enterprises to take the initiative to undertake social responsibility, hoping to provide some help to scholars in related fields and practitioners in enterprises.
\end{abstract}

Keywords: tourism listed company; Social responsibility; Operating performance

\section{Introduction}

In recent years, with the continuous development of economy and the deepening of sustainable development concept, enterprises are constantly expanding economic benefits, but also facing the public requirements of social responsibility. The issue of social responsibility of enterprises has been paid more and more attention at home and abroad. During the two sessions in 2019, the State Council made a deployment for the development of tourism, and put forward new requirements for the tourism industry, as a strategic pillar industry of national economy and a modern service industry satisfying the people. It fully promoted the integration of culture and tourism, and continuously improved the quality of tourism through cultural guidance. The rapid development of tourism industry provides a new economic growth point for the overall development of economy, and plays a strong role in supporting. Because tourism enterprises have strong dependence on environment and nature, and are closely related to the problems in the field of social responsibility of environmental protection and social development, the social responsibility of tourism enterprises is particularly important for its sustainable development.

But in recent years, in the process of development, the problems of destroying the ecological environment, excessive scenic spots development and forcing tourists to consume are still frequent. This phenomenon seriously restricts the development of tourism enterprises, affects the external image of tourism enterprises, seriously damages their operating performance, and also reflects the serious lack of social responsibility of tourism enterprises. Under this background, it is of great practical significance to study the social responsibility of tourism enterprises.

From the perspective of foreign studies, there are plenty of research on the social responsibility of listed tourism companies and enterprises. The first concept of corporate social responsibility was proposed by Oliver, a British scholar, who proposed that corporate social responsibility as a measure should be far higher than the profit of enterprises in the science of management [1]. Bowen also put forward a milestone definition of corporate social responsibility in the book "social responsibility of entrepreneurs" [2], and also the beginning of the whole theoretical

ISSN: 0010-8189

(C) CONVERTER 2021

www.converter-magazine.info 
system construction. After that, many scholars have elaborated, and divergent views have been drawn.

At present, the theoretical system of corporate social responsibility in the academic circle is relatively complete. The influence of social responsibility on the business efficiency of enterprises abroad is divided into two groups: one is the opposition of corporate social responsibility led by Friedman, the Nobel Prize winner of economics, and the other is the support group of corporate social responsibility. Generally speaking, the impact of social responsibility and business benefits is mainly positive, that is, the enterprises actively undertake social responsibility, which helps to improve the business efficiency of enterprises.

From the domestic research on social responsibility, domestic research in recent years has also started to carry out related fields. First, most of the domestic scholars still focus on the theoretical research, or financial analysis of the current situation, and then carry on the new index construction. Generally speaking, there is still a lack of empirical research, but in recent years, the research on empirical research is increasing. Li yaohui (2014) summarized the domestic and foreign studies and put forward the future development direction [3]. He Hui (2018) directly analyzes the status quo of social responsibility of listed tourism companies [4]. Secondly, in the aspect of breadth, the research involves all the enterprise fields, with the largest number of banking and manufacturing industries, and the number of cross research on tourism industry is relatively small. Most of the domestic related researches still involve the financial structure, governance structure, diversification and other aspects of financial management. The research object of the state-owned enterprises is Shan Chunxia (2018) [5]. Zhao Xia (2017) studies the correlation between grain and oil enterprises and operating performance from the perspective of food security [6].

Therefore, for the tourism field, many theoretical and empirical research on tourism industry is necessary. This paper chooses the research topic of tourism special for the social responsibility of listed companies to its performance of the impact of such a research topic still has a certain practical significance.

\section{Hypothesis and Research Design}

\section{1 assumption}

According to the above theory and research analysis, combined with the pyramid theory, this paper divides the social responsibility of listed companies into four parts: economic responsibility, legal responsibility, ethical responsibility, charity responsibility and environmental responsibility. Combined with the stakeholder theory, under the economic responsibility, it can be divided into the social responsibility to shareholders, creditors and consumers. Under the legal responsibility, it is divided into social responsibility to employees and the government. Under the ethical responsibility and philanthropic responsibility, enterprises generally have to bear the social responsibility for the community and the public. Finally, the environmental responsibility of ecological nature. Therefore, this paper puts forward the following hypotheses on the impact of social responsibility of tourism listed companies on business performance

First of all, the company needs to bear certain social responsibility to the economic stakeholders [7]. It includes the social responsibility for shareholders and creditors to ensure the profitability and solvency of the company. And the social responsibility of providing quality and cheap products to consumers, so as to enhance consumers' loyalty to the enterprise. Obviously, these social responsibilities can improve the company's operating system, increase sales performance, and improve the company's operating performance. Different from manufacturing enterprises, tourism enterprises are less dependent on suppliers. Therefore, this paper selects three types of economic stakeholders: shareholders, creditors and consumers. Therefore, hypothesis 1 is proposed

Hypothesis 1: Tourism Listed Companies' social and economic responsibility has a positive impact on their business performance.

ISSN: 0010-8189

(C) CONVERTER 2021

www.converter-magazine.info 
Hypothesis 1A: the corporate social responsibility of tourism listed companies has a positive impact on their business performance.

Hypothesis 2A: the corporate social responsibility of listed tourism companies has a positive impact on their business performance.

Hypothesis 3A: the corporate social responsibility of tourism listed companies has a positive impact on their business performance.

Secondly, employees and the government are the important legal liability stakeholders of listed companies [8]. Listed companies provide employees with job opportunities and pay them salaries in accordance with relevant labor laws and regulations, so as to ensure their self-improvement in the enterprise. At the same time, listed companies operate according to law, solve the employment problem for the government, support the work of the government, respond to the policies related to enterprises, and promote the economic development of surrounding areas. On the contrary, when the personal ability of employees is improved, the business performance of enterprises will also be improved. Employees' recognition of the enterprise will also reduce labor disputes. Because most of the jobs in tourism enterprises are of service nature, the improvement of employee's treatment will correspondingly improve customer satisfaction. The positive response to government work will be supported and tilted by relevant government policies, so as to form a good political development environment, which is also conducive to the listed enterprises to improve business performance. Therefore, hypothesis 2 is proposed

Hypothesis 2: the social legal responsibility of tourism listed companies has a positive impact on their business performance.

Hypothesis 2A: the social responsibility of tourism listed companies has a positive impact on their business performance.

Hypothesis 2B: the government social responsibility of tourism listed companies has a positive impact on their business performance.

Thirdly, the development of enterprises must rely on the local public and community, which is the requirement of ethical responsibility and charitable responsibility in corporate social responsibility. The public and the community provide certain human resources guarantee and material resources support for enterprises. Actively fulfill the social responsibility for the public and the community, and carry out related charity activities, which will help to form a good corporate atmosphere and effectively enhance the reputation of enterprises in the local. Therefore, hypothesis 3 is proposed.

Hypothesis 3: Tourism Listed Companies' social ethical responsibility and charitable responsibility have a positive impact on their business performance. Or the public and community responsibilities of tourism listed companies have a positive impact on their business performance.

Finally, as an issue of environmental responsibility that has attracted much attention in recent years, for the tourism industry, this issue is the focus of attention. Most scenic spots and even hotels need to rely on the surrounding natural and geographical environment to maximize the benefits. Therefore, listed tourism enterprises must consciously take social responsibility for the environment. They can't just talk about development and ignore environmental protection. Only green waters and green mountains are the golden and silver mountains for sustainable development of enterprises [9]. Therefore, Hypothesis 4 is proposed.

Hypothesis 4: Tourism Listed Companies' social environmental responsibility has a positive impact on their business performance.

ISSN: 0010-8189

(C) CONVERTER 2021 


\section{2 research design}

2.2.1 sample selection

According to the list of listed companies such as "industry classification results of Listed Companies in the fourth quarter of 2018" issued by China Securities Regulatory Commission, this paper clarifies the tourism listed companies mentioned in this paper. Then the paper selects A-share listed companies in Shanghai and Shenzhen stock exchanges from 2014 to 2018 as samples for empirical research. In the process of preliminary screening and processing of sample data, this paper excluded the tourism listed companies with the research period of ST and Pt, the companies with significant changes in business scope from 2014 to 2018, and the tourism enterprises listed after 2014, and selected 23 tourism enterprises.

\subsection{2 data sources}

All the data used in this paper are mainly from the official website of Shanghai and Shenzhen Stock Exchange, CNKI and guotai'an database, as well as the official website of China Securities Regulatory Commission, National Tourism Administration and National Bureau of statistics. The annual financial reports of tourism listed companies are basically from the official websites of Shanghai and Shenzhen stock exchanges. Relevant data and financial indicators vary according to different listed companies. In this paper, excel is used for data statistics and Eviews is used for data analysis.

\section{3 index selection}

\subsection{1 corporate social responsibility index selection}

In addition to financial indicators, there are also non-financial indicators to measure corporate social responsibility. This part of the content of this paper is mainly empirical analysis, so combined with the "pyramid" theory and stakeholder theory, the index selection here is mainly based on financial indicators, supplemented by non-financial indicators.

\section{1) Economic responsibility}

In the "pyramid" theory, economic responsibility requires enterprises to provide valuable products or services for consumers, and requires enterprises to make economic stakeholders, such as shareholders and creditors, profit from it [10]. As a result, under the economic responsibility index, there are shareholder responsibility index, creditor responsibility index and consumer responsibility index.

\section{(1) Shareholder responsibility index}

The reason why shareholders choose to invest in a certain enterprise is that the enterprise can make them profit. On the contrary, only by ensuring the continuous investment of shareholders' funds, can the enterprise operate normally. Therefore, in the economic responsibility of enterprises, to ensure that shareholders can make profits is the most important social responsibility. According to the relevant enterprise index research, this paper mainly uses earnings per share as the financial index to measure the economic responsibility of enterprises. This index can comprehensively reflect the degree of protection for shareholders' interests and the profit of shareholders' investment in the enterprise. Generally speaking, the higher the value of earnings per share, the more profits the shareholders make in the enterprise, and the higher the degree of the company meeting the shareholders' profit goals, so the higher the company's social responsibility to shareholders. The calculation formula of earnings per share is as follows: Earnings per share $=$ net profit $/$ weighted average of issued common stock

(2) Creditor liability index

When the enterprise is in a crisis of capital chain fracture and lack of liquidity, creditors mainly provide financial support to help enterprises through difficulties. Therefore, in the scope of economic responsibility, creditors are also

ISSN: 0010-8189

(C) CONVERTER 2021 
important stakeholders. When the creditor provides the enterprise with the service of fund lending, the breeding enterprise shall bear considerable social responsibility to the creditors, mainly in order to pay off the principal and interest in time to ensure the safety of the creditor's funds. The higher the value of the asset liability ratio, the stronger the ability of the company to pay the interest of creditors, and the higher the security of the funds provided by the creditors to the enterprise. The calculation formula of the asset liability ratio is as follows:

Asset liability ratio $=$ Total Liabilities $/$ total assets

(3) Consumer responsibility index

For enterprises, the number and loyalty of consumers are the key to the success or failure of enterprises. The more products or services consumers buy, the better the business benefits of the enterprise will be. Especially for the tourism and other service industries, consumer satisfaction is everything. Enterprises should provide high-quality products and services for customers and be responsible for the satisfaction of consumers. This is the reason why the enterprise exists and the need of the rapid development of the enterprise. Referring to the research of domestic and foreign scholars, this paper selects the cost rate index of main business to measure the responsibility of enterprises to consumers [11]. First, the higher the cost rate of the main business means that the more the enterprise invests in the products or services, the higher the value of the products or services consumers can get, and also means that the enterprise is continuously improving the quality of the products or services provided by consumers, and the higher the quality that the consumer can obtain. The specific formula of this indicator is as follows:

Cost rate of main business $=$ cost of main business $/$ income of main business

2) Legal liability

When carrying out business activities, enterprises must bear the legal responsibility of legal operation within the scope of the law. The stakeholders formed according to legal responsibility include employees of the enterprise and the local government of the enterprise. Thus, the employee responsibility index and the government responsibility index are formed.

\section{(1) Employee responsibility index}

As the main labor force of the enterprise, the employees and enterprises are mutually beneficial on the basis of labor contract. The enterprise pays the employees the remuneration of their labor and the cost of basic living security, and also bears the social responsibility of training and re education of employees. The growth of employees means the growth of business performance. In the tourism industry, the work content of employees is mostly of service nature. Employees are the most important human capital in the operation of enterprises, and the first door to face consumers directly. Tourism enterprises should bear more social responsibilities to employees [12]. Therefore, according to the particularity of tourism enterprises, this paper selects two financial indicators, namely, the profit level of employees and the proportion of education funds to income to measure the social responsibility of employees. The higher the level of employee profit means the higher the investment and attention the enterprise has on the employees, and also indicates that the enterprise is more willing to invest in the personal promotion of employees. The specific calculation formula of the two indexes is as follows:

Employee profit level $=$ Cash $/$ main business income paid to employees and employees

Proportion of staff education funds to income $=$ enterprise pays staff education funds $/$ main business income

(2) Government responsibility index

ISSN: 0010-8189

(C) CONVERTER 2021

www.converter-magazine.info 
The government macro-control of the operation of economic market provides an indispensable political environment for the sustainable development of enterprises [13]. Therefore, enterprises also have considerable social responsibility to the government. In the concrete action, the tax is mainly paid according to law. Therefore, in this paper, we choose the asset tax rate index related to tax to measure the social responsibility of enterprises to the government. The higher the tax rate, the greater the contribution of the enterprise to tax. The specific calculation formula of the index is as follows:

Tax rate of assets $=$ total tax paid by enterprises $/$ total average assets

3) Ethical and charitable responsibilities

As a part of society, enterprises need to undertake certain ethical and charitable responsibilities for the public and society through various ways. In the process of enterprise management, enterprises need to feedback the society and the public, and fulfill their social responsibilities to the public and the government through charitable donations and public welfare activities, which is conducive to improving the reputation of the enterprise in the local areas [14]. Therefore, this paper selects the index of enterprise donation rate. If the index value is higher, the higher the attention of listed enterprises to local communities and the public, the higher the return rate to the community and the public. The calculation formula of enterprise donation rate is as follows:

Enterprise donation rate $=$ social donation amount $/$ main business income

4) Environmental responsibility

In recent years, with the influence of relevant policies, the public has put forward higher requirements for the social environmental responsibility that enterprises should fulfill. Especially, tourism, which relies on the development of natural ecological environment to a large extent, is the most important of all social responsibilities [15]. In the social responsibility report of enterprises, the description of environmental responsibility indicators is generally disclosed through non-financial indicators. Therefore, this paper chooses the non-financial index of whether the environmental protection information is disclosed by enterprises as the standard to evaluate the environmental responsibility of enterprises.

If environmental protection information is disclosed in public information, the value is 1 , and if it is not disclosed, it will be taken as 0 .

\subsection{2 selection of operating performance indicators}

As an indicator of the overall performance of an enterprise, according to the relevant research of domestic and foreign scholars, this paper chooses the total asset return rate which can best reflect the business operation and profitability of the enterprise as an independent variable to directly measure the performance of the enterprise in a certain period. The specific calculation formula of return on total assets is as follows:

Total return on assets $=$ net profit $/$ average total assets

\subsection{3 control variables}

In the previous empirical research, the ownership nature and scale of the company will have a certain impact on the results of the study [16]. Therefore, in this paper, we select two non-financial indicators of the company size and equity nature as the control variables. As shown in Table 1.

The value of state-owned holding is 1 , and the other values including private ownership are 0 .

The company size is taken as the natural logarithm of the total assets of the company.

ISSN: 0010-8189

(c) CONVERTER 2021

www.converter-magazine.info 
Table 1 variable selection of regression model

\begin{tabular}{|c|c|c|c|c|c|}
\hline type & classification & Variable Name & symbol & expect & computational method \\
\hline $\begin{array}{l}\text { Depend } \\
\text { ent } \\
\text { variable }\end{array}$ & $\begin{array}{c}\text { Enterprise } \\
\text { Performance }\end{array}$ & $\begin{array}{l}\text { all capital earnings } \\
\text { rate }\end{array}$ & $\mathrm{ROA}$ & + & Net profit / total average assets \\
\hline \multirow[t]{8}{*}{$\begin{array}{l}\text { Autovar } \\
\text { iable }\end{array}$} & $\begin{array}{l}\text { financial } \\
\text { responsibility }\end{array}$ & earnings per share & EPS & + & $\begin{array}{l}\text { Net profit / weighted average of } \\
\text { the ordinary shares issued outside }\end{array}$ \\
\hline & & asset-liability ratio & CRE & + & Total liabilities / total assets \\
\hline & & $\begin{array}{l}\text { Main business } \\
\text { cost rate }\end{array}$ & CUS & + & $\begin{array}{c}\text { Main Business Cost / Main } \\
\text { Business Income }\end{array}$ \\
\hline & legal liability & $\begin{array}{c}\text { Employee profit } \\
\text { level }\end{array}$ & EMP1 & + & $\begin{array}{l}\text { Cash / main business income paid } \\
\text { for employees }\end{array}$ \\
\hline & & $\begin{array}{l}\text { ratio of employee } \\
\text { education funds in } \\
\text { income }\end{array}$ & EMP2 & + & $\begin{array}{l}\text { Enterprise pays employee } \\
\text { education funds / main business } \\
\text { income }\end{array}$ \\
\hline & & $\begin{array}{l}\text { Asset tax payment } \\
\text { rate }\end{array}$ & PUB & + & $\begin{array}{c}\text { Total corporate taxes / total } \\
\text { average assets }\end{array}$ \\
\hline & $\begin{array}{l}\text { Ethics } \\
\text { Responsibilit } \\
\text { y and Charity } \\
\text { Responsibilit }\end{array}$ & $\begin{array}{l}\text { Enterprise } \\
\text { donation rate }\end{array}$ & $\mathrm{COV}$ & + & $\begin{array}{l}\text { Corporate and social donation } \\
\text { amount / main business income }\end{array}$ \\
\hline & $\begin{array}{c}\mathrm{y} \\
\text { Environmenta } \\
1 \\
\text { responsibility }\end{array}$ & $\begin{array}{l}\text { Whether the } \\
\text { environmental } \\
\text { protection } \\
\text { information is } \\
\text { disclosed }\end{array}$ & ENV & + & $\begin{array}{l}\text { If the environmental protection } \\
\text { information is disclosed in the } \\
\text { public information, the value is } 1 \text {, } \\
\text { and if not disclosed, the value is } 0\end{array}$ \\
\hline \multirow{2}{*}{$\begin{array}{l}\text { explanat } \\
\text { ory } \\
\text { variable }\end{array}$} & & Enterprise nature & GY & + & $\begin{array}{l}\text { State-owned holding value } 1 \text { and } \\
\text { others including private value } 0\end{array}$ \\
\hline & & company size & SIZE & + & $\begin{array}{l}\text { Natural logarithm of the total } \\
\text { company assets }\end{array}$ \\
\hline
\end{tabular}

2.4 model construction

According to the relevant empirical research of domestic and foreign scholars, this paper constructs the following model

Model 1: $\mathrm{y}=\alpha 0+\alpha$ 1EPS $+\alpha 2 \mathrm{CRE}+\alpha 3 \mathrm{CUS}+\alpha$ 9SIZE $+\alpha 10 \mathrm{GY}+\varepsilon$

Model 2: $\mathrm{y}=\alpha 0+\alpha \mathrm{EMP} 1+\alpha$ 5EMP $2+\alpha 6 \mathrm{COV}+\alpha$ 7PUB $+\alpha$ 8ENV $+\alpha$ 9SIZE $+\alpha$ 10GY $+\varepsilon$ Lag model: $\mathrm{y}=\alpha 0+\alpha$ $1 \mathrm{EPS}+\alpha 2 \mathrm{CRE}+\alpha 3 \mathrm{CUS}+\alpha$ 4EMP1 $+\alpha 5 \mathrm{EMP} 2+\alpha 6 \mathrm{COV}+\alpha 7 \mathrm{PUB}+\alpha 8 \mathrm{ENV}+\alpha$ 9SIZE $+\alpha 10 \mathrm{GY}+\varepsilon$ Among them, $\mathrm{Y}$ represents the return on total assets (ROA) and represents the operating efficiency of the enterprise. EPS represents earnings per share, CRE represents asset liability ratio, cus represents the cost ratio of main business, and represents the social and economic responsibility of the enterprise to relevant stakeholders. Emp1 represents the profit level of employees, emp2 represents the proportion of labor union and employee education funds in income. CoV refers to the rate of tax payment, representing the social legal responsibility of the enterprise to the relevant stakeholders. Pub represents the corporate donation rate, representing the ethical and charitable responsibilities of the company to the society and the public. Env means whether an enterprise discloses environmental information, which represents its social responsibility for the environment. Size refers to the scale of the enterprise, Gy refers to the nature of the equity of the enterprise, these two are the control variables in the regression equation. last $\varepsilon$ Represents the random error term.

ISSN: 0010-8189

C CONVERTER 2021 


\section{Empirical Analysis}

\section{1 descriptive statistics}

Since the reform and opening up, tourism, as the leading industry of the tertiary industry and the strategic pillar industry of the national economy, has developed rapidly. In the 13th five year plan, the state has put forward new requirements for the tourism industry and made new policy guidance. In such a good political and economic environment, tourism enterprises have a strong momentum of development and become a high-profile industry in the economic market.

\subsection{1 current situation of Tourism Listed Companies}

In the development report of China's listed tourism companies in 2016, 65 listed tourism enterprises are selected as samples for research. The total market value of these enterprises is 406.32 billion yuan. Among them, there are 60 enterprises landing on the domestic capital market, with a total market value of 357.23 billion yuan. Among these listed enterprises, there are 25 main board enterprises. There are 5 small and medium-sized enterprises, 2 Gem enterprises and 28 listed enterprises in the new third board. In addition, there are 5 enterprises landing on the Hong Kong Stock Exchange and 5 domestic enterprises landing on the overseas market, including 4 enterprises landing on NASDAQ and 1 enterprise landing on the New York Stock Exchange. Compared with previous years, the overall market value of domestic tourism listed companies has shown a significant growth trend. At the same time, the capital market for the tourism industry is not only hot, but also shows an overall trend of increasing year by year.

Listed tourism enterprises basically include scenic spots, hotels and travel agencies. Because tourism enterprises have comprehensive industry characteristics, the business scope of enterprises is not limited to one aspect. Large enterprises often include "food, housing, transportation, tourism, shopping and entertainment". In recent years, the operation and development of listed tourism enterprises are more diversified, which also promotes the overall layout of China's tourism market to be increasingly perfect, and can meet the diverse needs of tourism consumers. At the same time, as the leading enterprise of the tertiary industry, tourism is also actively integrating with other industries to create more enterprise value. It is precisely because of the uniqueness of tourism enterprises that the research on the social responsibility of tourism enterprises is becoming more and more important.

\subsection{2 disclosure status of social responsibility of Tourism Listed Companies}

Since the promulgation of the "corporate governance standards for listed companies" in 2002, it has made clear provisions on the performance of corporate social responsibility and the disclosure of corporate social responsibility. As the leader of the tertiary industry, tourism listed companies are the leader of the development of the whole industry. Compared with other traditional industries, it is easier to learn from foreign excellent management methods. Therefore, we must take the lead in the disclosure of social responsibility. According to the case analysis of domestic scholars, the characteristics of social responsibility of Tourism Listed Companies in China are as follows: firstly, although more and more tourism listed companies consciously undertake social responsibility with the growth of time, the form of social responsibility still needs to be improved and the level also needs to be improved. Secondly, the means of fulfilling social responsibility of China's tourism listed companies are constantly expanding, and the field of undertaking social responsibility is also expanding.

Generally speaking, the level of social responsibility of tourism enterprises is continuously improving, but in the face of the public, the disclosure of social responsibility of tourism listed companies is still not optimistic. Most of the listed companies still do not disclose corporate social responsibility reports separately, but include them in the annual statements of listed companies as a part. According to the relevant data analysis, up to now, among the tourism enterprises listed in China's A-share market, only 9 enterprises have issued social responsibility reports, while a total of 4 enterprises have issued corporate social responsibility reports for five consecutive years, which is obviously unsatisfactory.

Generally speaking, there are two parts in the content of social responsibility report disclosure of tourism listed

ISSN: 0010-8189

(C) CONVERTER 2021

www.converter-magazine.info 
companies. One is to divide the dimensions according to the stakeholder theory, and explain the performance of social responsibility of each stakeholder. Generally speaking, this part of information is disclosed by financial indicators. Second, the company in a certain period of time for social responsibility related public welfare, charitable activities, this part of the information is mainly text-based, which leads to this part of the information disclosure with a certain subjectivity of the enterprise, and the lack of quantifiable indicators. Most of the social responsibility information disclosed by enterprises is positive, while the negative information is ignored selectively, which will lead to the incomprehensibility and subjectivity of the disclosure.

To sum up, although tourism listed companies have made great progress in fulfilling their social responsibilities, there is still a large space for development in information disclosure.

Table 2 descripptive statistical results of sample tourist listed Companies

\begin{tabular}{|c|c|c|c|c|c|c|}
\hline Variables & & $\begin{array}{l}\text { Numbe } \\
\mathrm{r}\end{array}$ & $\begin{array}{l}\text { Minimum } \\
\text { value }\end{array}$ & $\begin{array}{l}\text { Maximum } \\
\text { value }\end{array}$ & $\begin{array}{l}\text { Average } \\
\text { value }\end{array}$ & $\begin{array}{l}\text { Standard } \\
\text { difference }\end{array}$ \\
\hline ROA & & 115 & -.1078 & .1647 & .048996 & .045070 \\
\hline EPS & & 115 & -.469 & 1.8522 & .401875 & .394545 \\
\hline CRE & & 115 & .0441 & .8030 & .405131 & .252045 \\
\hline CUS & & 115 & .0536 & .9372 & .538625 & .216637 \\
\hline EMP1 & & 115 & .0076 & 6315 & .196505 & .115973 \\
\hline EMP2 & & 115 & .00 & .0114 & .00317 & .003231 \\
\hline $\mathrm{COV}$ & & 115 & .0003 & .1521 & .040929 & .023177 \\
\hline PUB & & 115 & .00 & .0166 & .000765 & .002539 \\
\hline ENV & & 115 & .00 & 1.00 & .539130 & .500648 \\
\hline SIZE & & 115 & 8.7609 & 11.4686 & 8.7609 & .531863 \\
\hline GY & & 115 & .00 & 1.00 & .826087 & .380693 \\
\hline $\begin{array}{l}\text { Valid } \\
\text { Column) }\end{array}$ & $\mathrm{N}$ (in & 115 & & & & \\
\hline
\end{tabular}

As shown in Table 2, According to the overall descriptive statistics in the chart, the mean value of the total return on assets of the explained variable is 0.048996, and there is a significant difference between the maximum and minimum values, which indicates that the development of Tourism Listed Companies in China is unbalanced and the operating performance is quite different.

Among the explanatory variables, the minimum value of EPS is -0.469 , the maximum value is 1.8522 , and the average value is 0.401875 , which indicates that there are great differences in the profitability of different tourism listed companies.

Similarly, the explanatory variable asset liability ratio (CRE) also has obvious differences, with the maximum value of 0.8030 and the minimum value of 0.0441 , which means that different companies choose different ways of operation. On the whole, the cre of China's tourism listed companies is 0.405131 , which means that most of the listed companies have a relatively stable way of operation without excessive liabilities.

ISSN: 0010-8189

(C) CONVERTER 2021 
The average value of main business cost ratio (CUS) is 0.538625 . On the one hand, the tourism industry has more investment in human and material resources, and the cost is also relatively high, which can also reflect the profit of listed companies for consumers.

As a typical labor-intensive industry, the average value of the explanatory variable emp1 is 0.196505 , but the maximum value of the proportion of labor union and employee education funds to income (emp2) is only 0.0114 , which indicates that enterprises do not pay enough attention to employee training and sustainable growth.

The maximum value of tax payment rate $(\mathrm{COV})$ is 0.1521 , and the minimum value is only 0.0003 , which indicates that the development level of China's tourism listed companies is still uneven, and the social responsibility to the government is limited. The average value of the explanatory variable of social donation rate (PUB) is about 0.00076 , which indicates that the social responsibility of listed companies for the public and the community is not enough and needs to be further improved. Among the 23 listed companies, only about 0.539 have disclosed environmental protection information, which is not optimistic.

In terms of control variables, there is a large gap in the scale of listed tourism companies in China, with the maximum value of 11.4686 and the minimum value of 8.7609. Generally speaking, the development level is uneven. Finally, most of China's tourism listed companies are still state-owned, and about 0.826 companies belong to state-owned enterprises.

\section{2 empirical analysis process}

\subsubsection{Hausmann test}

Table 3 Housman Testing Table

\begin{tabular}{ccc}
\hline Test Summary & test statistic & Adjoint probabilities $(\mathrm{P})$ \\
\hline Data random values & 6.111234 & 0.6348 \\
\hline
\end{tabular}

As shown in Table 3,Use the Hausmann test in Eviews to determine the specific types of panel data in this paper. The original hypothesis of Hausmann test is that individual effect has nothing to do with regression variables. According to the data analysis, the $\mathrm{p}$ value of each explained variable is much greater than 0.05 . Therefore, the original hypothesis can be accepted, and a random effect model should be established for regression analysis.

\subsection{2 current regression analysis}

As shown in Table 4, The relevant data of 23 listed companies are analyzed by Eviews, and the statistical data are as follows. ROA is the dependent variable.

Table 4 Model 1 Regression Analysis Results

\begin{tabular}{|c|c|c|c|c|}
\hline $\begin{array}{l}\text { varia } \\
\text { ble }\end{array}$ & Model 1 & Assuming 1a & Assuming $2 \mathrm{a}$ & Assuming $3 \mathrm{a}$ \\
\hline $\begin{array}{c}\text { const } \\
\text { ant }\end{array}$ & $.191244(2.352575)$ & $\begin{array}{c}.380123 \\
(4.601446)\end{array}$ & $\begin{array}{c}-.144586 \\
(-1.663825)\end{array}$ & $\begin{array}{c}0.068422 \\
(0.011317)\end{array}$ \\
\hline EPS & $.081704(8.505100)$ & $\begin{array}{c}.095155 \\
(9.570737)\end{array}$ & NA & NA \\
\hline CRE & $-0.096370(-5.006006)$ & NA & $\begin{array}{c}-.145979 \\
(-6.338530)\end{array}$ & NA \\
\hline CUS & $\begin{array}{c}0.013505 \\
(0.901272)\end{array}$ & NA & NA & $\begin{array}{c}0.011317 \\
(0.486358)\end{array}$ \\
\hline SIZE & $\begin{array}{c}-0.012660 \\
(-1.423444) \\
\end{array}$ & $\begin{array}{c}-0.037422 \\
(-4.330965)\end{array}$ & $\begin{array}{c}.028116 \\
(2.988419)\end{array}$ & $\begin{array}{c}-0.004138 \\
(-0.374380)\end{array}$ \\
\hline GY & -0.026481( & -0.009587 & .023218 & 0.018897 \\
\hline
\end{tabular}




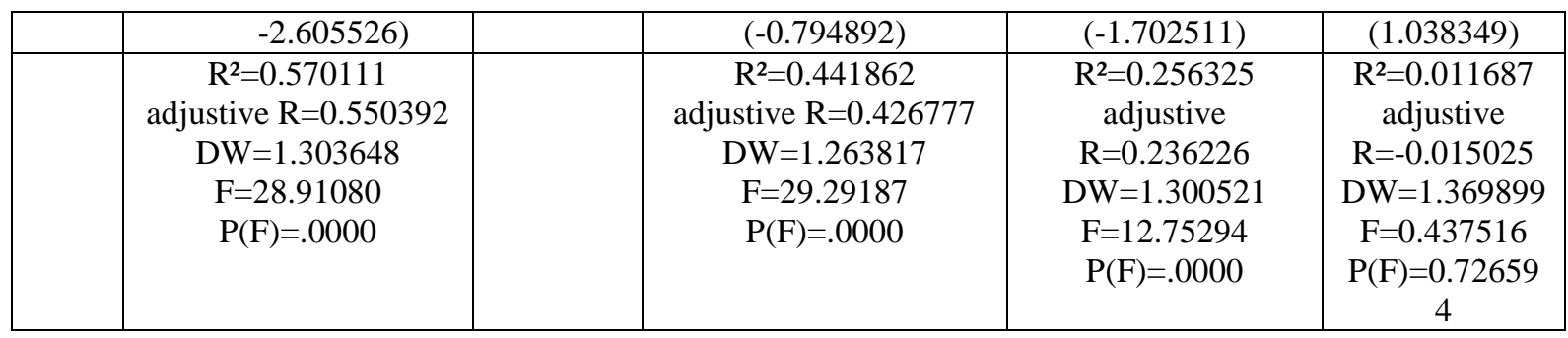

According to the analysis results, the regression equation of model one is as follows $\mathrm{y}=\alpha 0+0.08 \mathrm{EPS}-0.10 \mathrm{CRE}+0.01 \mathrm{CUS}-0.01$ SIZE-0.02GY $+\varepsilon$

Table 5 Model II Regression Analysis Results

\begin{tabular}{|c|c|c|c|c|c|}
\hline Variables & Model II & Assuming $2 \mathrm{~b}$ & Assuming $2 \mathrm{~b}$ & Model III & Model IV \\
\hline constant & $\begin{array}{l}.044031 \\
(.498465)\end{array}$ & $\begin{array}{c}.239466 \\
(2.251146)\end{array}$ & $\begin{array}{c}-.094500 \\
(-1.093327)\end{array}$ & $\begin{array}{c}.081479 \\
(.785941)\end{array}$ & $\begin{array}{c}.073084 \\
(0.686266)\end{array}$ \\
\hline EMP1 & $\begin{array}{c}-.099917 \\
(-3.38780)\end{array}$ & $\begin{array}{c}-.097177 \\
(-2.840669)\end{array}$ & NA & NA & NA \\
\hline EMP2 & $\begin{array}{l}-.287295 \\
(-.21597)\end{array}$ & $\begin{array}{c}-2.227001 \\
(-1.401584)\end{array}$ & NA & NA & NA \\
\hline $\mathrm{COV}$ & $\begin{array}{c}.956282 \\
(7.050992)\end{array}$ & NA & $\begin{array}{c}1.007209 \\
(7.167546)\end{array}$ & NA & NA \\
\hline PUB & NA & NA & NA & $\begin{array}{c}-2.570386 \\
(-2.205778)\end{array}$ & NA \\
\hline ENV & NA & NA & NA & NA & .000284 \\
\hline SIZE & $\begin{array}{l}-.001491 \\
(-.16987)\end{array}$ & $\begin{array}{c}-.018771(-1.74 \\
5227)\end{array}$ & $\begin{array}{c}.010957 \\
(1.245828)\end{array}$ & $\begin{array}{l}-.004399 \\
(-.413095)\end{array}$ & $\begin{array}{l}-.003803 \\
(-.346451)\end{array}$ \\
\hline GY & $\begin{array}{c}.002268 \\
(.180089)\end{array}$ & $\begin{array}{c}.021556 \\
(1.305354)\end{array}$ & $\begin{array}{l}-.002665 \\
(-.193982)\end{array}$ & $\begin{array}{l}.015879 \\
(.910946)\end{array}$ & $\begin{array}{l}.016508 \\
(.926046)\end{array}$ \\
\hline & $\begin{array}{c}\mathrm{R}^{2}=0.38968 \\
\text { adjustive } \\
\mathrm{R}=0.361685 \\
\mathrm{DW}=1.73869 \\
\mathrm{~F}=13.91906 \\
\mathrm{P}(\mathrm{F})=0.0000\end{array}$ & $\begin{array}{c}\mathrm{R}^{2}=0.13180 \\
\text { adjustive } \\
\mathrm{R}=0.100230 \\
\mathrm{DW}=1.53590 \\
\mathrm{~F}=4.174769 \\
\mathrm{P}(\mathrm{F})=0.00347 \\
1\end{array}$ & $\begin{array}{c}\mathrm{R}^{2}=0.30627 \\
\text { adjustive } \\
\mathrm{R}=0.287522 \\
\mathrm{DW}=1.66179 \\
\mathrm{~F}=16.33501 \\
\mathrm{P}(\mathrm{F})=.0000\end{array}$ & $\begin{array}{c}\mathrm{R}^{2}=0.04734 \\
\text { adjustive } \\
\mathrm{R}=0.021596 \\
\mathrm{DW}=1.42988 \\
\mathrm{~F}=1.838748 \\
\mathrm{P}(\mathrm{F})=0.14427 \\
0\end{array}$ & $\begin{array}{c}\mathrm{R}^{2}=0.00812 \\
\text { adjustive } \\
\mathrm{R}=-0.01868 \\
\mathrm{DW}=1.34684 \\
\mathrm{~F}=0.302971 \\
\mathrm{P}(\mathrm{F})=0.82319 \\
0\end{array}$ \\
\hline
\end{tabular}

As shown in Table 5,According to the analysis results, the regression equation of model 2 is as follows $\mathrm{y}=\alpha-0.1 \mathrm{EMP} 1+0.29 \mathrm{EMP} 2+0.95 \mathrm{COV}-2.57 \mathrm{PUB}+0.0002 \mathrm{ENV}-0.01 \mathrm{SIZE}+0.02 \mathrm{GY}+\varepsilon$

First of all, according to the analysis data in the table, we can know that earnings per share (EPS), tax payment rate $(\mathrm{COV})$, corporate donation rate (PUB) and environmental information disclosure (Env) are positively correlated with return on total assets (ROA), among which corporate donation rate (PUB) and environmental information disclosure (Env) are positively correlated with dependent variables, But it was not significant. Therefore, the hypotheses 1a and $2 \mathrm{~b}$ mentioned above are true, while hypotheses 3 and 4 are not completely consistent with the analysis results, that is, hypotheses 3 and 4 are not completely true.

There are negative correlation with ROA: CRE, cus, emp1, emp2, size and Gy. Among them, the main business cost ratio (CUS) and the proportion of trade union and staff education funds in income (emp2) are negatively correlated with the dependent variables, but not significantly. It can be concluded that the analysis results are consistent with hypothesis $2 \mathrm{a}$, but not with hypothesis $1 \mathrm{~b}$ and $3 \mathrm{a}$, that is, hypothesis 1 and hypothesis 2 are not fully tenable.

\subsection{3 lag effect test}

Because the disclosure of corporate social responsibility information takes time, it is impossible for the public to

ISSN: 0010-8189

C CONVERTER 2021 
know the commitment of corporate social responsibility in the first time. Therefore, the impact of corporate social responsibility on the performance of listed companies may lag behind. Therefore, this paper will carry out the regression analysis of corporate current social responsibility travel and lagging one and two business performance respectively. As shown in Table 6.

Table 6 Results

\begin{tabular}{|c|c|c|}
\hline variable & Late Phase I & Late Phase II \\
\hline constant & $.130533(1.14787)$ & $.155937(1.040028)$ \\
\hline EPS & $.043605(2.979859)$ & $.077400(4.334810)$ \\
\hline CRE & $-.068177(-2.557344)$ & $-.022458(-0.673749)$ \\
\hline CUS & $.017080(0.828923)$ & $.016561(0.588047)$ \\
\hline EMP1 & $-.056804(-1.360353)$ & $-.043146(-.813226)$ \\
\hline EMP2 & $-1.787204(-1.372624)$ & $.937039(.538732)$ \\
\hline $\mathrm{COV}$ & $.44484(2.793392)$ & $.121059(.596779)$ \\
\hline PUB & $.564947(.408215)$ & $-1.560631(-.322250)$ \\
\hline ENV & $.000637(.096731)$ & $-0.002199(-.271011)$ \\
\hline SIZE & $-.005476(-.453135)$ & $-.010801(-.700022)$ \\
\hline GY & $-.035611(-3.344119)$ & $-.035316(-2.430261)$ \\
\hline & $\begin{array}{c}\mathrm{R}^{2}=.482052 \\
\text { Adjusted } \mathrm{R}=.418108 \\
\mathrm{DW}=2.051571 \\
\mathrm{~F}=7.538631 \\
\mathrm{P}(\mathrm{F})=.0000\end{array}$ & $\begin{array}{c}\mathrm{R}^{2}=.416347 \\
\text { Adjusted } \mathrm{R}=.315718 \\
\mathrm{DW}=1.953461 \\
\mathrm{~F}=4.137417 \\
\mathrm{P}(\mathrm{F})=.000247\end{array}$ \\
\hline
\end{tabular}

From regression analysis, we can see that $\mathrm{R}^{2}$ the value is 0.482 , which is close to 1 . Therefore, it shows that there is a strong correlation between independent variable and dependent variable, and the fitting degree of regression equation is better, and the sample data has certain representativeness. DW value is 2.051 , which is very close to 2 , which indicates that the model has strong independence and does not have the autocorrelation in the sequence. And in the table, we can see that the significance of $\mathrm{F}$ value is $0, \mathrm{P}$ value is far less than 0.1 , which shows that the social responsibility performance of the listed tourism company studied in this paper has a significant linear relationship with the company's performance.

First, according to the analysis data in the table, EPS and co vare positively correlated with the total asset return (ROA). Among them, although the ratio of corporate donation (PUB), the cost rate of main business (CUS) and environmental information disclosure (Env) are positively correlated with dependent variables, they are not significant. Therefore, the assumptions $1 \mathrm{a}$ and $2 \mathrm{~b}$ mentioned in the previous article are true, while hypothesis $3 \mathrm{a}$, hypothesis 3 and Hypothesis 4 are not fully consistent with the analysis results, namely, hypothesis $3 a$, hypothesis 3 and Hypothesis 4 are not fully true.

There are significant negative correlation with the total asset return (ROA): the ratio of assets and liabilities (CRE), the level of employee profit (emp1), the proportion of labor union and staff education funds to income (emp2), and

ISSN: 0010-8189

C CONVERTER 2021 
the equity nature (Gy). Although the natural logarithm (size) of total assets is negatively correlated with dependent variables, it is not significant. It can be concluded that the analysis results are in accordance with assumptions $2 \mathrm{a}$ and 1b. In conclusion, hypothesis 2 is established and hypothesis 1 is not fully true.

According to the analysis results, the regression equation under the criterion of lag period is as follows:

$\mathrm{y}=+0.44 \mathrm{EPS}-0.07 \mathrm{CRE}-0.07 \mathrm{CUS}-0.07 \mathrm{EMP} 1+0.02 \mathrm{EMP} 2+0.44 \mathrm{COV}+0.56 \mathrm{PUB}+0.0006 \mathrm{ENV}-0.01 \mathrm{SIZE}-0.04 \mathrm{GY}+\varepsilon$ The data of the second phase lag can be seen by regression analysis ${ }^{2}$ The value is 0.416 , close to 1 . Therefore, it shows that there is a strong correlation between independent variable and dependent variable, and the fitting degree of regression equation is better, and the sample data has certain representativeness. DW value is 1.953 , which is very close to 2, which indicates that the model has strong independence and does not have the autocorrelation in the sequence. And in the table, we can see that the significance of $F$ value is 0.000247 , which is far less than 0.1 , which shows that the social responsibility performance of the listed tourism company studied in this paper has a significant linear relationship with the company's performance.

First, according to the analysis data in the table, EPS has a significant positive correlation with the total asset return (ROA). Although the main business cost rate (CUS), tax payment rate (COV), labor union and employee education expenditure to income ratio (emp2) are positively correlated with dependent variables, they are not significant. Therefore, hypothesis $1 \mathrm{~A}$ mentioned in the previous article is true, while hypothesis $3 \mathrm{a}$, hypothesis $1 \mathrm{~b}$ and $2 \mathrm{~b}$ are not fully consistent with the analysis results, namely hypothesis 3a, hypothesis 3 and Hypothesis 4 are not fully true.

Only the equity nature (Gy) has a significant negative correlation with the total asset return (ROA). Although the relationship between the asset liability ratio (CRE), the profit level of employees (emp1), the enterprise donation rate (PUB), the environmental information disclosure (Env) and the natural logarithm of total assets (size) are negatively correlated with dependent variables, they are not significant. In conclusion, hypothesis 2 and hypothesis 1 are not fully established.

According to the analysis results, the regression equation of the second phase lag is as follows:

$\mathrm{y}=+0.08 \mathrm{EPS}-0.02 \mathrm{CRE}+0.02 \mathrm{CUS}-0.04 \mathrm{EMP} 1+0.94 \mathrm{EMP} 2+0.12 \mathrm{COV}+-1.56 \mathrm{PUB}-0.002 \mathrm{ENV}-0.01 \mathrm{SIZE}-0.04 \mathrm{GY}+\varepsilon$

\subsection{4 discussion of research results}

According to the above descriptive statistics and regression analysis, it is concluded that the social responsibility of tourism listed companies has a positive impact on the business efficiency. For different stakeholders, there will be differences in the regression analysis of the current social responsibility on the current operating efficiency and the current social responsibility on the lag operating performance.

1) On the performance of economic responsibility

For the fulfillment of shareholders' social responsibility, in the current regression analysis and lag regression analysis, EPS and ROA always show a significant positive correlation, which is fully consistent with hypothesis $1 \mathrm{a}$. The analysis results show that enterprises actively fulfill their social responsibilities to shareholders, protect the economic rights and interests of shareholders and capital security, which is conducive to enterprises to obtain more investment and support, so as to effectively improve the business performance of enterprises.

For the performance of creditors' social responsibility, in the regression analysis of the current social responsibility on the current operating efficiency and the current social responsibility on the lagging operating performance, the asset liability ratio (CRE) and the return on total assets (ROA) always show a negative correlation, but the significance has changed. The lower the asset liability ratio is, the stronger the debt paying ability of the enterprise is. At the same time, it shows that the enterprise actively performs its social responsibility to the creditors, repays the

ISSN: 0010-8189

(C) CONVERTER 2021

www.converter-magazine.info 
principal and interest in time, and can establish a good reputation of the enterprise, so as to reduce the financing pressure of the enterprise and improve the business performance of the enterprise.

For the fulfillment of consumer social responsibility, in the regression analysis results of the current social responsibility on the current operating efficiency, the main business cost ratio (CUS) and the return on total assets (ROA) show a negative correlation, but the significance is not high, which is not consistent with the hypothesis 3 a. However, in the regression analysis of the current social responsibility on the lag operating performance, there is no significant positive correlation between the main business cost ratio (CUS) and the return on total assets (ROA).

As a typical labor-intensive industry, the tourism industry needs to invest a lot of human and material resources to operate in order to achieve the future return. However, the payback period is often long. Therefore, in the short term, the main business cost remains high. However, there is no significant positive correlation between the main business cost and the return on total assets (ROA) between the lagged phases 1 and 2, The input of human and material resources can get slow response from consumers, gradually build up consumer loyalty, so as to improve the later business performance to a certain extent.

\section{2) Performance of legal responsibility}

For the performance of employees' social responsibility, in the regression analysis of the current social responsibility on the current operating efficiency and the current social responsibility on the lagging operating performance, the employee profit level (emp1), the proportion of labor union and employee education funds in income (emp2) are negatively correlated with the return on total assets (ROA), but not significantly, This shows that hypothesis $1 \mathrm{~b}$ does not hold. In the regression analysis of the current social responsibility commitment on the lagging business performance, emp1, emp2 and ROA show a significant negative correlation. It was not until the second lag period that the proportion of labor union and staff education funds in income (emp2) showed no significant positive correlation with the rate of return on total assets (ROA).

This shows that the listed tourism companies do not pay enough attention to their employees. Although they can show a slow rising trend, they still need to make further efforts. This situation is mainly because the tourism enterprises need huge human resources, so the level of internal staff is uneven, and the enterprises also treat employees differently. In addition, tourism enterprises have two seasons. The long-term off-season tourism will make tourism listed companies reduce the cost of human resources, resulting in low enthusiasm of employees and insufficient loyalty to enterprises.

For the government to fulfill its social responsibility, in the regression analysis of the current social responsibility on the current operating efficiency and the current social responsibility on the lag operating performance, the tax payment rate $(\mathrm{COV})$ and the return on total assets (ROA) always show a significant positive correlation, and the hypothesis $2 \mathrm{~b}$ is true. This fully shows that enterprises actively pay taxes, legitimate and reasonable operation is conducive to the relevant support of the government, so as to effectively improve the business performance of enterprises.

\section{3) Ethical responsibility and charitable responsibility}

For the local community and the public to fulfill their social responsibility, in the regression analysis of the current social responsibility on the current operating efficiency and the current social responsibility on the lag operating performance, the enterprise donation rate (PUB) and the return on total assets (ROA) show no significant positive correlation, hypothesis 3 is not fully tenable. In the regression analysis of the current social responsibility on the lag period of business performance, the lag period 1 shows no significant positive correlation, while the lag period 2 shows no significant negative correlation.

ISSN: 0010-8189

(C) CONVERTER 2021 
First of all, it shows that the corporate social responsibility for the local community and the public is not enough. In the face of the community and the public to carry out public welfare activities, donations and charity can improve the reputation of the enterprise, establish the image of the enterprise, and then improve the business performance of the enterprise. But the related public welfare behavior needs a certain degree of sustainability, charitable behavior also needs sustainable development, in order to bring considerable good influence to the enterprise.

4) Environmental responsibility

As for the disclosure of environmental information, in the regression analysis of the current social responsibility on the current operating efficiency and the current social responsibility on the lag operating performance, there is no significant positive correlation between the corporate donation rate (PUB) and the return on total assets (ROA), and the hypothesis 4 is not completely true. In the regression analysis of the current social responsibility on the lag period of business performance, the lag period 1 shows no significant positive correlation, while the lag period 2 shows no significant negative correlation, and the standard error becomes larger.

The first reason for this kind of abnormal data is that the tourism industry does not belong to the heavy pollution industry stipulated by the state, so the tourism industry has not paid enough attention to environmental protection. At the same time, the disclosure of environmental protection information is not ideal. Although it is not ruled out that some scenic spots will list the details of environmental protection, most enterprises still choose to use the way of text description for disclosure, which may also lead to inaccurate conclusions of the analysis.

\section{Research Suggestions}

According to the analysis and research of this paper, the active undertaking and fulfilling of social responsibility will have a positive impact on the business performance of the enterprise to a certain extent, and the positive impact has a certain lag. Domestic scholars have put forward a lot of suggestions for many stakeholders in the social responsibility. Therefore, this paper will give the following suggestions to the listed tourism companies in China, aiming at the current situation of social responsibility undertaking of China's tourism listed companies, as well as the analysis results obtained in the previous article.

4.1 strengthen the awareness of corporate social responsibility and strengthen the construction of relevant activities

First, as the main person in charge of the business performance, the management of listed companies should fully understand the relevant theoretical knowledge of corporate social responsibility, which is an important premise for the social responsibility of enterprises to be undertaken and fulfilled [17]. The management of listed companies should fully realize that the enterprises consciously and actively undertake social responsibility have a positive and positive impact on the business performance of the enterprises. Therefore, the management of listed companies has the responsibility and obligation to raise the corporate social responsibility to the strategic level of the enterprise. When making the enterprise regular development plan, the social responsibility of the enterprise is also taken into account. Learn from the excellent experience of domestic and foreign enterprises in fulfilling social responsibility and establish the sense of social responsibility.

Secondly, we should also regularly train and educate the employees of enterprises on the relevant knowledge of corporate social responsibility, and infiltrate the social responsibility of enterprises from top to bottom into all aspects of enterprise management. Employees are the important stakeholders of enterprises participating in social activities and fulfilling social responsibilities. Enterprises not only have certain social responsibility for employees, but also many related people need employees to take the initiative to bear social responsibility. In the process of training, the content of corporate social responsibility can not only make the employees establish the correct sense of corporate social responsibility, cooperate with various related activities organized by the enterprise, but also improve the personal knowledge level of employees and stimulate more active creation of social responsibility.

ISSN: 0010-8189

(C) CONVERTER 2021 
4.2 strengthen the performance of stakeholders' responsibilities and actively disclose information

According to the empirical research in this paper, enterprises pay more attention to the economic and social responsibility when they perform social responsibility, while facing other stakeholders, enterprises lack of attention to them and travel related responsibilities. Therefore, as a labor-intensive industry and tourism enterprises closely related to the environment, they should have more humanistic feelings, not just pay attention to the responsibility of economic stakeholders.

For employees, not only should they fulfill the enterprise responsibilities stipulated in the labor contract, guarantee the normal life of the employees, but also improve the salary and welfare system and pay attention to the situation of each employee. We should create fair and fair promotion space, pay attention to the personal growth of employees, and carry out various corporate cultural activities to enhance the loyalty of employees to the enterprise. For the service industry, the loyalty and professionalism of employees are the biggest premise of consumer satisfaction. Only by realizing the common development of employees and enterprises can enterprises get better development space.

For consumers, the listed companies in tourism industry should take the satisfaction of consumers as their own responsibility, follow the needs of consumers, adjust their business strategies in time, provide consumers with high-quality products with good quality and low price, and fulfill the commitments made by enterprises to consumers in accordance with the prior contract. Moreover, establish a complete after-sales service system and consumer complaint system, and return the customer satisfaction, and solve the problems in time. Build customer loyalty to the enterprise.

For the surrounding public and community, the listed tourism companies must build the rights and interests of the residents around China. We are enthusiastic about public welfare, carry out various activities and establish excellent corporate image. Instead of donating money and goods, we should interact with surrounding communities in combination with the advantages of their own tourism enterprises. For example, the activities of caring for autistic children and the activities of science popularization education carried out by relevant tourist attractions are closely related to the surrounding public communities.

For the ecological environment, enterprises should not only infiltrate the concept of environmental protection into the corporate culture, but also practice them in the business activities. To build an environment-friendly tourism enterprise. And timely disclosure of relevant environmental protection information to the public, not because it is not the key emission unit stipulated by the state, it has ignored environmental protection. At the same time, the listed tourism companies relying on tourism resources should not only actively maintain the local natural environment, but also protect the local cultural landscape, intangible cultural heritage and other tourism resources. After all, these are the important foundation for the development of tourism.

We should summarize, sort out and record the social responsibilities of stakeholders, actively disclose them to the public on a regular basis, publicize excellent series of public welfare activities, enhance the reputation of enterprises, and do not hide negative punishment information and respect the right to know of the public.

\section{Acknowledgements}

This research was supported by Xi ' an University of Science and Technology University Higher Education Research Project: Service Regional Economy Research on Growth Model and Countermeasures (Item Number GJY-2020-YB-8).

This research was supported by Xi ' an University of Science and Technology University Teaching Reform Project: "Market Research and Forecast" flipped classroom (2019).

ISSN: 0010-8189

(C) CONVERTER 2021 
This research was supported by Xi ' an University of Science and Technology University the Philosophy and Social Science Prosperity Project: Study on the Integrated Development of Culture and Tourism and High Quality of Shaanxi (2021).

\section{Reference}

[1] F.J.G. Rodríguez, Y.D.M.A. Cruz, "Relation between social-environmental responsibility and performance in hotel firms," International Journal of Hospitality Management, no. 4, 2006.

[2] R.M. Gargouri, R. Shabou, C. Francoeur, "The relationship between corporate social performance and earnings management," Canadian Journal of Administrative Sciences, no. 4, 2010

[3] Y.Q. Li, H. Fu, "Tourism corporate social responsibility: Research Review and prospect," Journal of tourism, vol. 29, no. 6, pp.107-116, 2014.

[4] H. He, "Analysis on the current situation of social responsibility accounting information disclosure of Tourism Listed Companies," Modern commerce and trade industry, vol. 39, no. 19, pp. 104-105, 2018.

[5] C.X. Shan, J. Cui, "Research on the impact of social responsibility strategy and business performance of state owned enterprises," Henan Social Sciences, vol. 26, no. 8, pp. 90-94, 2018.

[6] X. Zhao, Y. Li, J. Li, "Correlation analysis of social responsibility and business performance of grain and oil enterprises -- from the perspective of food security," Food science and technology and economy, vol. 42, no. 1, pp. 20-24, 2017.

[7] Y.Q. Li, "Research on the public response to the cessation of charitable social responsibility of tourism enterprises," Journal of tourism, vol. 31, no. 7, pp. 106-116, 2016.

[8] X.W. Wang, H. Chen, "Research on the relationship between corporate social responsibility and corporate value based on stakeholders," Management science, vol. 24, no. 06, pp. 29-37, 2011.

[9] M.M. Zhao, "Research on the impact of social responsibility performance on business performance of listed tourism companies in China," Heilongjiang University, 2018

[10] J.Y. Wang, "Research on the social responsibility model of China's tourism enterprises -- a case study of Hong Kong China Travel Service Group,” Economic Forum, no. 5, pp. 123-125, 2013.

[11] C. Zhang, S.X. Wu, "Environmental responsibility and enterprise performance: Theory and empirical study," Industrial technology and economy, vol. 36, no. 5, pp. 67-75, 2017.

[12] H. Wang, "Ownership, social responsibility and financial performance of tourism enterprises," Statistics and decision making, no. 20, pp. 179-181, 2015.

[13] W.B. Xu, "Research on enterprise performance evaluation from ecological perspective," Times finance, no. 24 , pp. $99+104,2018$.

[14] L.G. Tamajón, X. FontiAulet, "Corporate social responsibility in tourism small and medium enterprises evidence from Europe and Latin America," Tourism Management Perspectives, 2013

[15] M. Wagner. "The Effect of Corporate Environmental Strategy Choice and Environmental Performance on Competitiveness and Economic Performance,” European Management Journal, no. 5, 2004.

[16] W.W. Li, J. Wang, "Research on the correlation between tourism corporate social responsibility and business efficiency," Journal of tourism, vol. 28, no. 3, pp. 47-51, 2013.

[17] Y.L. Yi, "Research on the impact of food corporate social responsibility on business performance," Times finance, no. 32, pp 280-282 + 293, 2016. 